\title{
Test method for determining phosphate ions in organic products and soil using blister cells
}

\author{
(C) Sergey L. Belopukhov,${ }^{1 *+}$ Alexey V. Jevnerov, ${ }^{1}$ \\ Andrey V. Bochkarev, ${ }^{1}$ and Ravil F. Baibekov ${ }^{2}$ \\ ${ }^{1}$ Chemistry Department. ${ }^{2}$ Soil Science Department. Russian Timiryazev State Agrarian University. \\ Timiryazevskaya St., 49. Moscow, 127434. Russia. Phone: +7 (499)976-32-16.E-mail: belopuhov@mail.ru
}

\begin{abstract}
*Supervising author; ${ }^{+}$Corresponding author
Keywords: express methods of analysis, phosphate ions, silica gel, sorption, blister cell, photometry. chemical composition.
\end{abstract}

\begin{abstract}
A test method for the determination of phosphates in environmental objects has been developed, the determination of phosphate ions can be carried out in the field, the analysis of one sample is carried out for 1015 minutes. Color characteristics can be monitored both visually and using color processing programs for smartphones such as ON Color Measure or Light Analyzer. Variants of compositions of a series of placers are proposed for visually blister colorimetric determination of phosphate ion concentrations in a blister cell (tablet for tablets) containing a mixture of reagents. The placers allow the quantitative determination of phosphates in various objects without preliminary preparation of reagent solutions. The application of reagents to the surface of silica gel makes it possible to isolate all reagents until a chemical reaction occurs. Each component in a separate placer is isolated, stable for 6 months. Test systems are recommended for semi-quantitative visual testing and for the quantitative determination of the content of phosphate ions in solutions. The composition and application conditions of crystalline substances - reagents capable of providing a sufficiently high acidity with the addition of a few drops of a solution and a reducing agent suitable under blister conditions have been optimized. Visual-colorimetric reaction is carried out under conditions when the volume of the added solution is 2-3 drops. In the environmental objects of the Belogorsky district of the Republic of Crimea, the concentrations of phosphate ions in water samples, soil of carbonate chernozem, biomass of cellulose-containing waste of lavender after extraction of lavender essential oil grown by organic farming were determined. The phosphate content was estimated by the visual blister method in the samples and standard methods, and good convergence of the analysis results was shown.
\end{abstract}

\section{References}

[1] Y.A. Milenia. Adsorption of small ions. Adsorption from solutions on the surface of solids. Moscow: Mir. 1986. P.261-272. (russian)

[2] O.V. Eliseeva, A.F. Eliseev, S.L. Belopukhov. Application of near-infrared spectroscopy for basil chemical composition analysis. Butlerov Communications. 2019. Vol.60. No.12. P.152-156. DOI: 10.37952/ROI-jbc-02/19-60-12-152

[3] R.F. Baybekov, O.S. Mishina, S.L. Belopukhov, R.G. Ivanov, N.G. Rakipov. Investigation of the effect of the bioregulator "Etafosf" on the morphological parameters and productivity of buckwheat. Zemledeliye. 2019. No.5. P.41-45. (russian)

[4] Yu.I. Enakiev, E.A. Grishina, S.L. Belopukhov, I.I. Dmitrevskaya. Application of NIR spectroscopy for cellulose determination in flax. Bulgarian Journal of Agricultural Science. 2018. Vol.24. No.5. P.897901.

[5] G.G. Ivanova, A.A. Ivanov, O.A. Shpigun. Determination of phosphorus forms in natural waters. Bulletin of the Moscow University. Series 2. 1999. Vol.40. No.2. P.118-123. (russian)

[6] V.G. Sychev. The current state of soil fertility and the main aspects of its regulation. Moscow: RAN. 2019. 325p. (russian)

[7] S.L. Belopukhov, V.I. Savich, V.V. Gukalov, N.M. Saduakasov, K.S. Los, and E.M. Ilyushkova. Agroecological assessment of soil structure. Butlerov Communications. 2017. Vol.52. No.12. P.39-45. DOI: 10.37952/ROI-jbc-02/17-52-12-39 
TEST METHOD FOR DETERMINING PHOSPHATE IONS IN ORGANIC PRODUCTS AND SOIL USING... $92-98$

[8] Hamidreza Bayat, Sergei Belopukhov The effect of humic acid, plant growth promoting rhizobacteria and seaweed on growth parameters, essential oil and chlorophyll content in sweet basil (Ocimum basilicum l.). Global Scientific Journals. 2019. Vol.7. No.7. P.19-32

[9] V.I. Savich, S.L. Belopukhov, V.A. Sedikh, B.A. Barisov, and V.V. Gukalov. Assessment of optimal soil properties and lack of nutrients for plants using methods based on the principles of feedback. Butlerov Communications. 2018. Vol.55. No.7. P.120-125. DOI: 10.37952/ROI-jbc-02/18-55-7-120

[10] O.A. Biryukova, D.V. Bozhkov, V.V. Nosov. Comparative characteristics of methods for determining the content of mobile phosphorus in ordinary carbonate chernozem. Scientific Journal of KubGAU. 2014. No.103(09). P.1-12. (russian)

[11] S.L. Belopukhov, N.P. Buryakov. Chemical certification of agricultural products: a textbook with a laboratory workshop. Moscow: BIBKOM; TRANSLOG. 2017. 198p. (russian)

[12] Yu.A. Zolotov, V.M. Ivanov, V.G. Amelin. Chemical test methods of analysis. Moscow: URSS. 2002. 304p. (russian)

[13] Ye.I. Morosanova, A.A. Velikorodnyy, N.M. Kuz'min, YU.A. Zolotov. Method for the production of porous silicon dioxide modified with phosphorous-molybdenum heteropoly compounds. Patent RF No. 2139243. Published 10.10.1999. (russian)

[14] V.A. Tertykh, L.A. Belyakova. Chemical reactions involving the silica surface. Kiev: Naukova Dumka. 1991. 264p.

[15] Modified silicas in sorption, catalysis, and chromatography. Edited by G.V. Lisichkina. Moscow: Khimiya. 1986. 246p. (russian)

[16] Ye.I. Morosanova. Non-covalently immobilized silica-based analytical reagents for the concentration, separation, and determination of inorganic and organic compounds. Diss. doctor of Chemical Sciences. Moscow. MGU. 2001. 440p. (russian)

[17] S.L. Belopukhov, N.K. Syunyayev, Tyutyun'kova M.V. Environmental Chemistry. Moscow: Prospectus. 2016. 240p. (russian)

[18] V.M. Markina. Tabletach development of rapid methods for the determination of nitrate and nitrite in agricultural products. Diss. Cand. chemical sciences. Moscow: MSKHA. 1998. 183p. (russian)

[19] S.L. Belopukhov, N.P. Buryakov, M.A. Buryakova. Standardization and certification of feed and feed additives. Information and reference materials. Moscow: BIBKOM; TRANSLOG. 2017. 248p. (russian) 